\title{
Private Tutoring's Role on Helping Students: An Analyzation of Educational Panel Survey from a Junior High School in the Chinese Rural Area
}

\author{
Jiyun Cheng ${ }^{1}$ \\ ${ }^{1}$ Student of The Hill School, Pottstown, PA 19464, USA \\ Correspondence: Jiyun Cheng, Student of The Hill School, Pottstown, PA 19464 USA. E-mail: \\ jcheng23@thehill.org
}

Received: December 16, $2021 \quad$ Accepted: January 31, $2022 \quad$ Online Published: February 4, 2022

doi:10.5539/jel.v11n2p71 URL: https://doi.org/10.5539/jel.v11n2p71

\begin{abstract}
Based on a panel survey filled by seventh grade students, who studied in Shaxi Middle School located in Shaxi, Yunnan, China, after completing a semester of Online English Peer Tutoring Program, the research applied the data collected, including English Exam grades and background information, with Regression and Z-score to analyze the effectiveness of Private Tutoring. The analysis yields the following findings: private tutoring is effective for all students regardless of natural abilities and gender. By putting gender and mid-term exam grades into the regression, participants have an average of 2.161 percent points higher than non-participants. Also, male students benefit more from tutoring.
\end{abstract}

Keywords: education, private tutoring, China, middle school

\section{Introduction}

The Chinese Government issued a series of policies to regulate the private tutoring (Note 1) industry in August of 2021. The policies included commercialization for the tutoring agencies, reduction of students' tasks, and termination of teaching content beyond the school. Private tutoring has a long history in China. Parents tended to send their kids to private tutoring agencies as young as in kindergarten, hoping that their kids could exceed their peers to attend the top schools. According to "A New Era of Education: China Education Development Report 2018" from Deloitte China, China's educational market would reach 2.6836 trillion Chinese Yuan (414 billion US dollars) and was expected to reach 3.36 trillion Yuan (518.4 billion US dollar) by 2020. Tutoring agencies took more than 60 percent of the market with K12 \& STEAM (Science, Technology, Engineering, Art, and Mathematics) Education. This hundreds-of-billions-level market brought heavy financial pressure to the parents, especially for those with multiple children. The cost of raising children became a significant problem in China, and this problem would worsen as education became more expensive throughout the country. Nevertheless, parents' money seemed to be wasted: most private tutoring agencies only taught students what was going to be taught at school, meaning they learned nothing that enhanced their learning abilities but topics that were already taught in school. Thus, the government made laws to regulate this market. Beyond giving students a head start on schools' content, how effective is private tutoring? The Sanguo Organization is a non-profit organization that pairs high school students with peers in rural areas to help them with their academics. The program hired high school students in the big cities with fluent English to help the students in Shaxi Middle School, a middle school in Shaxi, Yunnan, which consists of many minorities and families that earn below the average income. The tutoring session was held online with two peer tutors teaching three students. The program already took place for a semester, and the peer tutors surveyed to examine its effectiveness. The research question is whether participating in the English Peer Tutoring Program is effective for students in the Shaxi Middle School. It analyzes the English test scores with other factors. Still, this does not diminish other potential benefits of peer tutoring, such as increasing confidence, chances to make new friends, and acceptance into elite schools. The remainder of Section 1, the Literature Review, discusses similar conducted research that had been done. Section 2 is the analysis, including an introduction to the survey, sample characteristics, regression analysis, regression analysis, and Z-score analysis. There is also an overall interpretation to conclude the section. In Section 3 is the conclusion and discussion for the entire paper. 


\section{Literature Review}

Researchers from the China Agricultural University in Beijing, China, conducted a similar study called "Does private tutoring improve student learning in China? Evidence from the China Education Panel Survey." Their analysis was based on surveys given to students from 28 different Chinese counties. They used various models to examine the effectiveness of private tutoring. They obtained the following outcomes: Female students, lowperforming students, and students with better-educated and wealthier parents would benefit more from the private tutoring than other students. Also, according to the group, "tutoring raised students' Chinese and math test scores by $0.10-0.14$ SDs and 0.07-0.09 SDs, respectively." Another research was done by researchers from Chuang-Ang University called "Do Private Tutoring Expenditures Raise Academic Performance? Evidence from Middle School Students in South Korea." They researched on measuring educational inputs and students' outcomes. Their results state that "The true effect of private tutoring remains, at most, modest."

\section{Method}

\subsection{Data}

\subsubsection{Survey}

The data analyzed in this study come from a panel survey conducted by the Sanguo NPO's researchers. The survey evaluated the effectiveness of the Online English Peer Tutoring Program. The survey consisted of a series of questions including demographic information, like name, gender, class, class ranking, and level of participation. For example, whether they participated in the program; level of self-perceived pressure; time of participation; periods of class taken in one semester; and satisfaction of the program, such as evaluation to the program, test scores before the participating the exam (mid-term exam), and English test scores after (final exam). The names collected were only used for identifying siblings and cousins. Everyone who participated in the survey should be of a similar age since they all came from the same grade. The survey only utilized the data of class, gender, whether someone participated, mid-term exam grade, and final exam grade for analysis. The team passed out 100 surveys equally to all five seventh-grade classes in Shaxi Middle School. The survey's data was based on responses from 25 boys and 25 girls, selected randomly with a 1 to 1 ratio of participation and ten from each class.

\subsubsection{Sample Characteristic}

In the samples, as stated above, 50 percent were boys, and the average age was 13 since they all came from Grade seven. It was their first year of learning English for most students since there was only one primary school that taught English in the entire town. Twenty-five students in the program and 25 did not as a control group. Also, it was notable that the Mid-term Exam was more challenging than the Final Exam, so the decline in grades did not always represent a regression of performance.

Table 1. Summary of 50 samples

\begin{tabular}{|c|c|c|c|c|c|c|c|}
\hline Mid-term Exam & & Final Exam & & Female & & Participation & \\
\hline Mean & 72.44 & Mean & 62.936 & Mean & 0.5 & Mean & 0.5 \\
\hline Median & 74 & Median & 64 & Median & 0.5 & Median & 0.5 \\
\hline Mode & 96 & Mode & 32 & Mode & 1 & Mode & 1 \\
\hline Standard Deviation & 16.239 & $\begin{array}{l}\text { Standard } \\
\text { Deviation }\end{array}$ & 15.164 & Standard Deviation & 0.505 & Standard Deviation & 0.505 \\
\hline Sample Variance & 263.721 & Sample Variance & 229.952 & Sample Variance & 0.255 & Sample Variance & 0.255 \\
\hline
\end{tabular}

Table 2. Summary by participation

\begin{tabular}{lllll}
\hline & Participants & \multicolumn{3}{l}{ Non-Participants } \\
\cline { 2 - 5 } & Mean & SD & Mean & SD \\
\hline Variants & & & & \\
Female (=1 if yes) & 0.52 & 0.102 & 0.48 & 0.102 \\
Mid-Term Exam & 77.36 & 3.294 & 67.52 & 2.945 \\
Final Exam & 67.18 & 2.928 & 58.692 & 2.950 \\
\hline
\end{tabular}

Note. The Mid-Term Exam was created by the school's teachers, which was more challenging than the Final Exam. The Education Bureau of Jianchuan County designed the Final for all seventh-grade students of the county.

The table shows that two more females participated than those who were non-participants. Also, participants have higher scores on both the mid-term exam and final exam. 


\subsection{Analyzation with Regression}

To thoroughly analyze the effectiveness of private tutoring, using regression was an essential tool by converting whether the survey participants are female and whether they participated in the online tutoring program from True or False into 1 and 0.

Table 3. Regression analysis of participation with final exam score

\begin{tabular}{lllll}
\hline & Coefficients & Standard Error & $t$ Stat & $P$-value \\
\hline Intercept & 58.692 & 2.939 & 19.968 & $6.781 \mathrm{E}-25^{* * *}$ \\
Participation $(=1$ if yes) & 8.488 & 4.157 & 2.042 & $0.047^{*}$ \\
\hline
\end{tabular}

Note. ${ }^{*} \mathrm{p}<0.05, * * * \mathrm{p}<0.001$.

The coefficient for participation is 8.488 , which means that the participating students had an average of 8.488 percentage points higher than the non-participating students. Note that the Online English Peer Tutoring Program selected students based on interest instead of English ability, and students had already participated in the program for a semester. Notice that participation in this model is potentially conflicting with the effect of other factors such as gender, class, mid-term exam score, parents' education, or native abilities.

Table 4. Regression analysis of gender with final exam score

\begin{tabular}{lllll}
\hline & Coefficients & Standard Error & $t$ Stat & $P$-value \\
\hline Intercept & 59.36 & 2.976 & 19.946 & $7.116 \mathrm{E}-25^{* * *}$ \\
Female (=1 if yes) & 7.152 & 4.209 & 1.699 & 0.096 \\
\hline
\end{tabular}

Note. ${ }^{* * \mathrm{p}}<0.001$

The coefficient for females was 7.152, indicating that female students had a significantly higher score on the Final Exam than the male students. This finding is not uncommon as found in other studies, such as the one done by researchers from China Agricultural University.

Table 5. Regression analysis of Mid-term exam score and final exam score

\begin{tabular}{lllll}
\hline & Coefficients & Standard Error & $T$-Stat & $P$-value \\
\hline Intercept & 15.203 & 7.086 & 2.145 & $0.037^{*}$ \\
Mid-term Exam & 0.659 & 0.095 & 6.900 & $1.047 \mathrm{E}-08^{* * *}$ \\
\hline
\end{tabular}

Note. $* \mathrm{p}<0.05, * * * \mathrm{p}<0.001$.

Since the coefficient was smaller than one, the average score for the Final Exam was about 0.659 times the Midterm Exam score. This result matched previous knowledge that mid-term was more challenging than the final.

Table 6. Regression analysis of Mid-term exam score, gender, and participation with final exam score

\begin{tabular}{lllll}
\hline & Coefficients & Standard Error & $t$ Stat & $P$-value \\
\hline Intercept & 15.638 & 7.223 & 2.165 & $0.036^{*}$ \\
Mid-term Exam & 0.631 & 0.104 & 6.0623 & $2.3328 \mathrm{E}-07^{* * *}$ \\
Female & 0.944 & 3.212 & 0.294 & 0.770 \\
Participation & 2.161 & 3.280 & 0.659 & 0.513 \\
\hline
\end{tabular}

Note. ${ }^{*} \mathrm{p}<0.05, * * * \mathrm{p}<0.001$.

By putting gender and mid-term exam grades into the regression, participation's coefficient is approximately 2.161 , still significant. An average of 2.161 points higher is already enough

to make a positive change for the students. If they can get two percent higher on their high school admission test, they might have a chance to attend a better high school. Thus, it is reasonable to say that participating in the program would help students in their English abilities and improve their grades. 


\subsection{Analyzation with Z-score}

As stated in Table 5, the mid-term exam was more challenging than the final exam, and most of the students (84 percent) got lower final scores than the mid-term. Therefore, to better analyze the program's effectiveness and avoid mistakes, converting both mid-term exam scores and final exam scores into Z-score would be a perfect idea.

Table 7. Regression analysis of mid-term exam Z-score and final exam Z-score

\begin{tabular}{lllll}
\hline & Coefficients & Standard Error & $t$ Stat & $P$-value \\
\hline Intercept & $-6.005 \mathrm{E}-16$ & 0.101 & $-5.932 \mathrm{E}-15$ & 1 \\
Mid-Term Z & 0.706 & 0.102 & 6.900 & $1.047 \mathrm{E}-08^{* * *}$ \\
\hline
\end{tabular}

Note. $* * * \mathrm{p}<0.001$.

Now, the coefficient is 0.7 , which means that for every standard point of the Mid-term Z-score, the final exam Zscore is 0.706 points standard deviation higher. This finding is consistent with Table 5 .

Table 8. Regression analysis of the Mid-term Exam Z-score, Gender, and Participation with Final Exam Z-score

\begin{tabular}{lllll}
\hline & Coefficients & Standard Error & $t$ Stat & $P$-value \\
\hline Intercept & -0.102 & 0.180 & -0.570 & 0.572 \\
Mid-Term $Z$ & 0.676 & 0.112 & 6.063 & $2.3328 \mathrm{E}-07^{* * * *}$ \\
Female $(=1$ if yes) & 0.062 & 0.212 & 0.294 & 0.770 \\
Participation (=1 if yes) & 0.142 & 0.216 & 0.659 & 0.513 \\
\hline
\end{tabular}
Note. ${ }^{* * \mathrm{p}}<0.001$

When applying the three essential factors together with the final exam score in Z-score, females' and participation coefficients of females and participation are still positive. Thus, it is reasonable to say that the program is effective for students. Also, the female students are doing better than male students on average.

Table 9. Regression analysis of all factors with final exam Z-Score

\begin{tabular}{lllll}
\hline & Coefficients & Standard Error & $t$ Stat & $P$-value \\
\hline Intercept & -0.075 & 0.326 & -0.229 & 0.820 \\
Mid-Term Z & 0.687 & 0.122 & 5.615 & $1.522 \mathrm{E}-06^{* * *}$ \\
Female (=1 if yes) & 0.138 & 0.309 & 0.446 & 0.658 \\
Interaction of Female and Participation (=1 if yes) & -0.196 & 0.449 & -0.436 & 0.665 \\
Participation (=1 if yes) & 0.236 & 0.315 & 0.750 & 0.458 \\
\hline
\end{tabular}

\begin{tabular}{cllll}
\hline Class 234 $(=1$ if yes $)$ & -0.333 & 0.356 & -0.938 & 0.354 \\
\hline Class 233 $(=1$ if yes $)$ & 0.073 & 0.360 & 0.203 & 0.840 \\
Class 232 $(=1$ if yes $)$ & -0.146 & 0.337 & -0.433 & 0.667 \\
Class 231 $(=1$ if yes) & 0.117 & 0.339 & 0.346 & 0.731 \\
\hline
\end{tabular}

Five more different factors are added. By creating an interaction between female scores and participation, the female students who participated in the program can now be analyzed. Since the coefficient is less than $0(-0.196)$, participation on Z-score is lower for women than men, but it is effective for women is still positive (0.04). Also, there are five different classes in seventh grade. By omitting Class 230, we can examine the differences between the five classes. Class 231 has a coefficient of 0.117 , which means they were the best among their grades. Class 233 has a coefficient of 0.073 , which is ranked second in their grade. Class 230, the control, ranked third in the grade. Class 232 and Class 234 are lower since their coefficients are less than 1.

\subsection{Overall Interpretation}

When analyzing whether something is effective, it is always hard to find an exact scale to test. The only way is to compare and find the relative difference. In the beginning, 25 female students and 25 male students were selected, and the participation ratio was 1 to 1 . Since the survey asked for their mid-term exam scores (before participating) and their final exam scores (after participating for one semester), we can analyze the difference in performance 
presented by test grade with half of the data as control. By applying Regression, we can tell the program's effectiveness by numbers. In Table 6, we incorporated participation, gender, and mid-term exam scores. The coefficient of participation is 2.161. This indicates those who participated have an average of 2.161 points higher than the ten who did not participate.

Moreover, as we apply a Z-score to the data, which could analyze the data accurately, the coefficient is still positive. Therefore, it is reasonable to state that the Online English Peer Tutoring Program is effective for students in Shaxi Middle School since it helps students improve their English abilities and grades. We can also predict that private tutoring is effective for students, and male students benefit more than female students.

\section{Conclusion \& Discussion}

Based on the analyses and interpretations that have been done, we can predict that private tutoring is an effective tool for helping students' academics and that male students can benefit more. Therefore, it raises a question: Why does the government wish to ban private tutoring? The answer is that it costs too much and brings students and their families into a vicious circle. In the past, no one attended those private tutoring agencies, and they competed with their classmates only based on what they had learned at school. However, when the first student got assistance off-campus, others followed since they all wished to get a better grade in standardized exams to attend a better school. Thus, attending a private tutoring agency gradually became "mandatory" for students - this need brought financial burden to the students' families and extra stress for them.

Nevertheless, it is still vital to help students who do not have quality education since they live in a rural area or their families earn below the average. Peer tutoring organized by a nonprofit organization is perfect for those students who wish to enrich their academics.

\section{Acknowledgement}

The author thanks Sanguo Organization and Shaxi Middle School for conducting the survey, especially to Miss Wei and Mr. Yang. The author is also grateful for helping 11 from Tianzi Jin, Xintian Song, Xingcen Liu, and Hongbo Zhang as his partners while conducting the survey. Financial supports from the parents are also sincerely appreciated.

\section{References}

Dolitte China. (2018). A new era of education China education development report 2018. Dolitte Global. Retrieved from http://www2.deloitte.com/content/dam/Deloitte/cn/Documents/technology-mediatelecommunications/deloitte-cn-tmt-china-education-development-en-report-2018.pdf

Guo, Y. H., Chen, Q. H., Zhai, S. Y., \& Pei, C. C. (2020). Does private tutoring improve student learning in China? Evidence from the China Education Panel Survey. Asia and the Pacific Policy Studies, 7(3), 322-343, https://doi.org/10.1002/app5.310

Ryu, D., \& Kang, C. H. (2013). Do Private Tutoring Expenditures Raise Academic Performance? Evidence from Middle School Students in South Korea. Asian Economic Journal, 27(1), 59-83. https://doi.org/10.1111/asej.12002

\section{Notes}

Note 1. http://www.moe.gov.cn/jyb_xxgk/moe_1777/moe_1778/202107/t20210724_546576.html

\section{Copyrights}

Copyright for this article is retained by the author, with first publication rights granted to the journal.

This is an open-access article distributed under the terms and conditions of the Creative Commons Attribution license (http://creativecommons.org/licenses/by/4.0/). 